\begin{tabular}{c|c} 
NABR & $\begin{array}{c}\text { Management and Business Review } \\
\text { Available at http://ejournal.unikama.ac.id/index.php/mbr } \\
\text { ISSN: } 2541-5808 \text { (online) } \\
\text { BUSINESS REVIEW }\end{array}$ \\
\hline
\end{tabular}

\title{
Pengaruh pembiayaan bermasalah dan kecukupan modal terhadap profitabilitas
}

\author{
Agus Taufik ${ }^{1}$, Nurhayati ${ }^{2}$, Sugeng Suprapto ${ }^{3}$ \\ 1,2,3 Program Studi Akuntansi STIE PGRI Dewantara Jombang, Indonesia \\ Email: agustaufik789@gmail.com
}

$\begin{array}{ll}\text { Article Info: } \\ \text { Receive } & \text { : April } 2018 \\ \text { Revised } & : \text { Mei } 2018 \\ \text { Accepted } & : \text { Juni } 2018 \\ \text { Published } & : \text { Juni } 2018 \\ \text { DOI } & : \text { 10.21067/mbr.v2i1.4618 } \\ \text { Copyright } & : \text { Management and } \\ & \text { Business Review }\end{array}$

Keywords:

Pembiayaan bermasalah, kecukupan modal, profitabilitas

\begin{abstract}
This study aims to examine the effect of problematic financing and capital adequacy on profitability at the Koperasi BMT Mu'amalah Syari'ah Tebuireng. This research uses descriptive quantitative research methods, with sampling using purposive sampling technique. The data used are secondary data. The data analysis technique used is the classical assumption test, multiple linear regression analysis and hypothesis testing. The results of the research based on testing show that problematic financing has an effect on profitability, while capital adequacy has no effect on profitability.Based on simultaneous testing, it shows that financing problems and capital adequacy have no effect on profitability.
\end{abstract}

\begin{abstract}
Abstrak: Penelitian ini bertujuan untuk menguji pengaruh pembiayaan bermasalah dan kecukupan modal terhadap profitabilitas pada Koperasi BMT Mu'amalah Syari'ah Tebuireng. Penelitian ini menggunakan metode penelitian deskriptif kuantitatif, dengan pengambilan sampel menggunakan teknik purposive sampling. Data yang digunakan adalah data sekunder. Teknik analisis data yang digunakan adalah uji asumsi klasik, analisis regresi linear berganda dan uji hipotesis. Hasil penelitian berdasarkan pengujian menunjukkan bahwa pembiayaan bermasalah berpengaruh terhadap profitabilitas, Sedangkan kecukupan modal tidak berpengaruh terhadap profitabilitas, Berdasarkan pengujian secara simultan menunjukkan bahwa pembiayaan bermasalah dan kecukupan modal tidak berpengaruh terhadap profitabilitas.
\end{abstract}




\section{Pendahuluan}

Semakin banyaknya kegiatan ekonomi masyarakat yang mengembangkan bisnis Usaha Mikro Kecil Menengah (UMKM), mengakibatkan jumlah persaingan usaha dalam berbagai sektor industri menjadi semakin meningkat. Untuk mengembangkan berbagai jenis usaha yang dilakukan oleh pelaku bisnis, maka diperlukan adanya daya dukung kecukupan dan ketersediaan modal yang besar. Melihat besar pengaruhnya modal dalam melakukan perkembangan usaha bisnis, menjadikan seseorang perlu mencari alternatif lembaga jasa keuangan yang mampu memenuhi kebutuhannya. Maka dari itu, peran lembaga keuangan menjadi sangat penting sebagai alternatif ketersediaan modal dalam upaya untuk mengembangkan usaha bisnis yang dijalankan. Hal ini didukung pula dengan berkembang pesatnya jumlah lembaga jasa keuangan seperti perbankan dan koperasi, baik yang berbasis sistem dengan prinsip konvensional maupun berbasis prinsip Islam (syariah) (Ervina \& Aridansari, 2016).

Perkembangan ekonomi dan lembaga keuangan Islam di Indonesia tampak menunjukkan kemajuan yang berarti. Terbukti pada tahun-tahun terakhir ini banyak sekali bermunculan lembaga keuangan yang berprinsip syariah. Di Indonesia, telah berkembang sangat pesat seperti lembaga keuangan syariah di era globalisasi ini yang berbentuk Baitul Maal wat Tamwil (BMT), (Aryani, 2015). BMT adalah salah satu produk dari lembaga keuangan syariah yang saat ini telah mampu memberikan pembiayaan untuk usaha anggota dan calon anggota agar usahanya dapat berkembang (Wigati \& Setiawan, 2014). Lembaga ini didirikan dengan maksud untuk memfasilitasi masyarakat bawah yang tidak terjangkau oleh pelayanan bank Islam atau BPR Islam. Prinsip operasional BMT didasarkan atas prinsip bagi hasil (profit and loss sharing), serta tidak menggunakan bunga sebagai alat untuk memperoleh pendapatan karena bunga merupakan riba yang diharamkan (Aryani, 2015).

BMT sangat berperan penting karena dapat membantu memenuhi keinginan sebagian kalangan masyarakat khususnya umat muslim yang menginginkan jasa layanan lembaga keuangan untuk mengelola perekonomiannya sesuai dengan ketentuan syariah (Aryani, 2015). Disamping menyalurkan dana atau memberikan pinjaman (kredit) juga melakukan usaha menghimpun dana dari masyarakat luas dalam bentuk simpanan dan menyalurkan kembali ke masyarakat dalam bentuk kredit serta dalam bentuk-bentuk lainnya dalam rangka meningkatkan taraf hidup orang banyak. Dari tiga kegiatan tersebut, pemberian kredit merupakan kegiatan keuangan yang paling dominan karena mengandung risiko yang tinggi (Ferdiansyah, 2011)

Kegiatan kredit ini tidak selamanya lancar, seiring dengan perkembangan koperasi juga mengalami kendala dalam penagihan kepada nasabahnya 
disebabkan banyak faktor-faktor yang mempengaruhi. Seperti faktor intern, ekstern, faktor makro ekonomi (terjadinya krisis moneter), dan faktor terjadinya suatu bencana alam. Sehubungan dengan terjadinya masalah tersebut, maka akan berpengaruh terhadap kegiatan perusahaan yang menimbulkan kredit bermasalah (Ferdiansyah, 2011). Kredit bermasalah (pembiayaan) adalah suatu penyaluran dana yang dilakukan oleh lembaga pembiayaan yaitu bank syariah yang dalam pelaksanaan pembayaran pembiayaan dikatakan macet, tidak berjalan lancar, pembiayaan yang debiturnya tidak memenuhi persyaratan yang dijanjikan, pembiayaan yang memiliki potensi menunggak dalam satu waktu tertentu, serta pembiayaan tersebut tidak menepati jadwal angsuran. Sehingga hal-hal tersebut dapat memberikan dampak negatif bagi kedua belah pihak yaitu shahibul maal dan mudharib (Usanti, 2013). Risiko kredit (pembiayaan) dapat diukur dengan menggunakan rasio Non Performing Loan (NPL) atau Non Performance Financing (NPF). Penggunaan rasio Non Performance Financing (NPF) untuk mengukur tingkat risiko pembiayaan ini, karena dalam perhitungan rasio NPF akan memberikan analisis deskripsi mengenai seberapa besar jumlah kredit yang mengalami masalah terhadap besarnya kredit yang telah disalurkan. Sehingga bank dapat melakukan manajemen risiko terhadap piutang yang dimilikinya, serta memanfaatkan simpanan dari nasabah untuk kegiatan yang produktif sebagai upaya menjaga tingkat profitabilitasnya (Ervina \& Aridansari, 2016).

Kecukupan modal merupakan salah satu faktor penting dalam rangka pengembangan usaha bisnis dan menampung risiko kerugian, semakin tinggi jumlah modal BMT dibandingkan dengan jumlah simpanan sukarela maka tingkat keamanan dana anggota semakin terjamin, dilihat dari sisi permodalan BMT situasi itu dinilai dalam kondisi sehat (Ulya, 2015). Melihat permintaan modal untuk perkembangan usaha yang semakin meningkat, serta kondisi keuangan BMT yang fluktuasi, kecermatan dalam menganalisis arus kas permodalan menjadi sangat penting. Kecukupan modal dan perlindungan terhadap risiko harus diperhatikan sebagai upaya menjaga tingkat kepercayaan masyarakat dan untuk menilai tingkat kesehatan lembaga keuangan (Ervina \& Aridansari, 2016). Kecukupan modal dapat diukur berdasarkan Capital Adequacy Ratio (CAR) (Kasmir, 2015). Penetapan Capital Adequacy Ratio (CAR) sebagai tolak ukur untuk menilai rasio permodalan sebagai upaya menjaga profitabilitas, didasarkan pada hubungannya dengan tingkat risiko yang mungkin terjadi di BMT. Sehingga hasil dalam perhitungan rasio CAR akan memberikan deskripsi terhadap sejumlah aktiva yang kemungkinan mengandung risiko untuk kegiatan operasional bank. Dimana besarnya CAR diukur berdasarkan rasio antara modal sendiri terhadap aktiva tertimbang menurut risiko (ATMR) (Rustam, 2013).

Aktifitas dalam melakukan kegiatan bisnis, selalu mengharapkan adanya keuntungan, keuntungan yang diperoleh dalam sistem operasional syariah adalah 
bagi hasil atas kegiatan pembiayaan kepada nasabah atau masyarakat anggota secara adil. Profitabilitas merupakan indikator yang paling tepat untuk mengukur kinerja suatu perusahaan, karena profitabilitas akan mencerminkan kemampuan perusahaan dalam memperoleh laba atau ukuran efektivitas pengelolaan manajemen perusahaan agar perusahaan mengetahui berapa laba yang diperoleh dalam suatu periode tertentu (Wiagustini, 2010). Indikator yang biasa digunakan oleh bank serta lembaga keuangan mikro lain untuk mengukur tingkat kesehatan bank dalam memperoleh keuntungan (profitabilitas) dapat ditunjukkan dengan rasio Return On Asset (ROA). Rasio ROA ini membandingkan laba bersih terhadap total aktiva, hal ini dapat dikatakan sebagai efektivitas perusahaan dalam menghasilkan laba dengan memanfaatkan aktiva yang dimilikinya (Ervina \& Aridansari, 2016), maka tujuan penelitian ini adalah sebagai berikut untuk mengetahui apakah pembiayaan bermasalah, kecukupan modal, berpengaruh terhadap profitabilitas pada Koperasi BMT Mu'amalah Syari'ah Tebuireng.

\section{Pembiayaan Bermasalah}

Pembiayaan bermasalah adalah suatu penyaluran dana yang dilakukan oleh lembaga pembiayaan yaitu bank syari'ah yang dalam pelaksanaan pembayaran pembiayaan dikatakan macet, tidak berjalan lancar, pembiayaan yang debiturnya tidak memenuhi persyaratan yang dijanjikan, pembiayaan yang memiliki potensi menunggak dalam satu waktu tertentu, serta pembiayaan tersebut tidak menepati jadwal angsuran. Sehingga hal-hal tersebut memberikan dampak negatif bagi kedua belah pihak yaitu shahibul maal dan mudharib (Usanti, 2013).

Kredit bermasalah atau problem loan dapat diartikan sebagai pinjaman yang mengalami kesulitan pelunasan akibat adanya faktor kesengajaan dan atau karena faktor eksternal diluar kemampuan kendali debitur. Kredit bermasalah sering juga disebut non performing loan atau non performing financing dalam perbankan syariah. NPL atau NPF keduanya merupakan bentuk yang sama dari perhitungan laporan keuangan yaitu berupa analisis rasio untuk penghitungan kredit bermasalah yang dihadapi bank. Analisis rasio keuangan dilakukan dengan tujuan untuk mengetahui kekuatan dan kelemahan perusahaan, informasi ini penting bagi pihak manajemen untuk mengevaluasi kinerja yang dicapai, dan menyusun rencana perusahaan ke depan (Sudana, 2016).

\section{Kecukupan Modal}

Kecukupan modal perusahaan perbankan dapat dilihat dari angka Capital Adequacy Ratio (CAR). Capital Adequacy Ratio (CAR) merupakan rasio keuangan sebagai tolak ukur penilaian tingkat kesehatan bank terhadap kecukupan modal yang dimiliki oleh setiap bank. Besarnya CAR diukur melalui rasio antara modal sendiri terhadap Aktiva Tertimbang Menurut Risiko (ATMR). Capital Adequacy 
Ratio (CAR) atau rasio kecukupan modal yaitu rasio kewajiban pemenuhan modal minimum yang harus dimiliki oleh bank (Riyadi, 2006).

Menurut Lukman (2009) Capital Adequacy Ratio (CAR) adalah rasio yang memperlihatkan seberapa besar jumlah seluruh aktiva bank yang mengandung unsur risiko (kredit, penyertaan, surat berharga, tagihan pada bank lain) yang ikut dibiayai dari modal sendiri bank, disamping memperoleh dana-dana dari sumbersumber diluar bank.

\section{Pembiayaan Bermasalah terhadap Profitabilitas}

Hasil penelitian menyatakan bahwa menyatakan bahwa pembiayaan bermasalah (NPF) berpengaruh terhadap ROA (Ma'isyah \& Mawardi, 2015; Malik, 2014). Pembiayaan bermasalah (NPF) merupakan salah satu indikator kesehatan kualitas aset, semakin tinggi NPF (diatas 5\%) maka bank tersebut tidak sehat dan NPF yang tinggi menurunkan profit yang akan diterima oleh bank. Ketika semakin tinggi pembiayaan bermasalah yang terdapat di bank menunjukkan bahwa bank tersebut tidak pandai dalam pengelolaan pembiayaannya, serta memberikan indikasi bahwa tingkat resiko atas pembiayaan yang ada di bank tersebut cukup tinggi searah dengan tingginya pembiayaan bermasalah yang dihadapi oleh bank yang berpengaruh terhadap profitabilitas. Ketika pembiayaan bermasalah melebihi batas maka peluang bank untuk mendapatkan keuntungan semakin menipis, pembiayaan bermasalah yang tinggi menyebabkan pendapatan bank menurun karena pembiayaan yang diberikan diawal tidak terbayarkan kembali kepada bank dalam jumlah dan waktu yang telah disepakati. Dengan demikian pembiayaan bermasalah (NPF) tinggi maka profitabilitas (ROA) akan rendah, sebaliknya ketika pembiayaan bermasalah (NPF) rendah maka profitabilitas (ROA) akan tinggi.

$\mathrm{H}_{1}$ : Pembiayaan Bermasalah berpengaruh terhadap Profitabilitas pada Koperasi BMT Mu'amalah Syari'ah Tebuireng.

\section{Pengaruh Kecukupan Modal terhadap Profitabilitas}

Pasaribu \& Sari (2011) dan Prasetyo \& Darmayanti (2015) menyatakan bahwa kecukupan modal (CAR) berpengaruh terhadap ROA. Kecukupan modal (CAR) yang tinggi akan memberikan efek yang positif bagi bank, karena modal yang dimiliki bank dapat digunakan untuk operasional bank tersebut baik melalui pemberian pembiayaan maupun dengan cara kpr dan lain-lain. Semakin tinggi nilai CAR yang dimiliki oleh bank (min $8 \%$ ) maka semakin baik pula profitabilitas (ROA), sebaliknya ketika rasio kecukupan modal (CAR) bank kecil akan berefek pada penurunan profitabilitas (ROA). Hal ini dikarenakan semakin besar modal ayang dimiliki maka kesempatan bank dalam mengoperasikan dananya semakin besar dan pendapatan yang diterima pun akan meningkat.

$\mathrm{H}_{2}$ : Kecukupan Modal berpengaruh terhadap Profitabilitas pada Koperasi BMT Mu'amalah Syari'ah Tebuireng. 


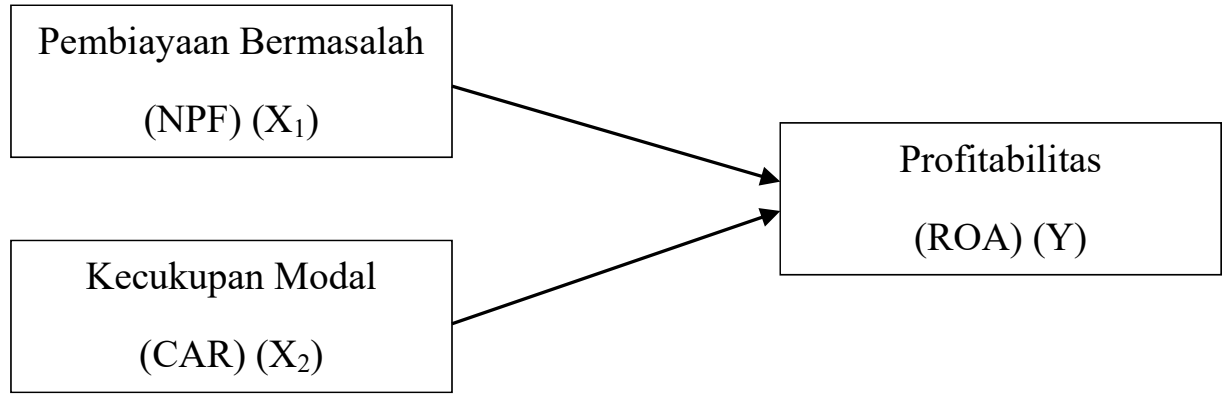

Gambar 1. Kerangka Konseptual

\section{Metode}

Rancangan penelitian ini menggunakan penelitian deskriptif kuantitatif. Penelitian ini dimaksudkan untuk mengetahui pengaruh pembiayaan bermasalah dan kecukupan modal terhadap profitabilitas pada Koperasi BMT Mu'amalah Syari'ah Tebuireng), sampel penelitian ini adalah laporan keuangan bulanan yang terdiri dari laporan neraca, laporan laba rugi, dan laporan kolektabilitas pembiayaan Koperasi BMT Mu'amalah Syari'ah Tebuireng selama 3 tahun, dalam penelitian ini teknik analisis data yang digunakan adalah analisis regresi linear berganda, dengan melakukan uji asumsi klasik.

\section{Hasil}

\section{Analisis Regresi Linear Berganda}

Analisis regresi digunakan untuk mengukur kekuatan hubungan antara dua variabel atau lebih, juga menunjukkan arah hubungan antara variabel dependen dengan independen. Analisis regresi linear berganda dilakukan dengan menggunakan SPSS versi 21.

Tabel 1. Hasil Analisis Regresi

\begin{tabular}{lcccl}
\hline \multicolumn{1}{c}{ Variabel } & Koefisien & $\mathbf{t}$ & Sig. & \multicolumn{1}{c}{ Hasil } \\
\hline Konstanta & .842 & & & \\
NPF & -.086 & -2.147 & .039 & Signifikan \\
CAR & -.006 & -1.051 & .301 & Tidak \\
& & & & Signifikan \\
\hline
\end{tabular}

\section{Variabel ROA}

terikat

Berdasarkan hasil analisis pada tabel 1, maka dapat dirumuskan persamaan regresi linear berganda sebagai berikut:

$\mathrm{Y}=0,842-0,086 \mathrm{X}_{1}-0,006 \mathrm{X}_{2}+\mathrm{e}$ 
Persamaan regresi diatas dapat dijelaskan sebagai berikut:

Nilai konstanta sebesar 0,842; artinya jika NPF $\left(\mathrm{X}_{1}\right)$ dan CAR $\left(\mathrm{X}_{2}\right)$ nilainya adalah nol, maka ROA (Y) nilainya adalah 0,842 .

Nilai koefisien regresi variabel NPF $\left(X_{1}\right)$ sebesar -0,086; artinya jika variabel independen lain nilainya tetap dan NPF mengalami kenaikan satu-satuan, maka ROA akan mengalami penurunan sebesar 0,086. Koefisien bernilai negatif artinya terjadi hubungan negatif antara NPF dengan ROA, semakin naik NPF maka semakin turun ROA.

Nilai koefisien regresi variabel CAR $\left(\mathrm{X}_{2}\right)$ sebesar -0,006; artinya jika variabel independen lain nilainya tetap dan CAR mengalami kenaikan satu-satuan, maka ROA akan mengalami penurunan sebesar 0,006. Koefisien bernilai negatif artinya terjadi hubungan negatif antara CAR dengan ROA, semakin naik CAR maka semakin turun ROA.

\section{Uji Hipotesis}

Uji hipotesis penelitian menggunakan Uji $t$, untuk mengetahui apakah variabel independen secara individual berpengaruh terhadap variabel dependen. Derajat kepercayaan yang digunakan adalah 0,05. Berdasarkan hasil analisis yang terdapat pada tabel 1 diperoleh nilai t hitung variabel NPF sebesar $(-2,147)$ dengan nilai signifikansi 0,039 sedangkan nilai t tabel 2,035 pada tingkat probabilitas (sig) 0,05. Maka dapat diketahui nilai $\mathrm{t}$ hitung 2,147 > t tabel 2,035 dan nilai signifikansi 0,039<0,05 dengan kata lain $\mathrm{H}_{1}$ diterima dan Ho ditolak, artinya secara parsial ada pengaruh antara NPF terhadap ROA. Jadi dapat disimpulkan bahwa pembiayaan bermasalah berpengaruh terhadap profitabilitas pada Koperasi BMT Mu'amalah Syari'ah Tebuireng.

Nilai t hitung variabel CAR sebesar $(-1,051)$ dengan nilai signifikansi 0,301 sedangkan nilai $t$ tabel 2,035 pada tingkat probabilitas (sig) 0,05. Maka dapat diketahui nilai thitung 1,051 < t tabel 2,035 dan nilai signifikansi 0,301 > 0,05 dengan kata lain $\mathrm{H}_{2}$ ditolak dan Ho diterima, artinya secara parsial tidak ada pengaruh antara CAR terhadap ROA. Jadi dapat disimpulkan bahwa kecukupan modal tidak berpengaruh terhadap profitabilitas pada Koperasi BMT Mu'amalah Syari'ah Tebuireng..

\section{Pembahasan}

\section{Pengaruh Pembiayaan Bermasalah terhadap Profitabilitas}

Berdasarkan hasil penelitian pada variabel pembiayaan bermasalah (NPF) dalam pengujian hipotesis pertama menunjukkan bahwa $\mathrm{H}_{1}$ diterima, dengan kata 
lain secara parsial variabel NPF berpengaruh terhadap ROA. Sehingga dapat disimpulkan bahwa pembiayaan bermasalah berpengaruh terhadap profitabilitas pada Koperasi BMT Mu'amalah Syari'ah Tebuireng. Hasil ini membuktikan semakin tinggi NPF maka ROA akan rendah. Hal ini dikarenakan adanya pembiayaan bermasalah yang tinggi akan dapat mengganggu perputaran modal kerja dari lembaga keuangan. Apabila lembaga keuangan memiliki jumlah pembiayaan bermasalah yang tinggi, maka akan mengakibatkan kehilangan kesempatan untuk memperoleh pendapatan dari pembiayaan yang diberikan.

Hasil penelitian ini sesuai dengan penelitian yang dilakukan oleh (Khusna, 2016), Ma'isyah \& Mawardi (2015), Malik (2014), Dewi \& Prasetiono (2011) yang menyatakan bahwa NPF berpengaruh terhadap ROA.

\section{Pengaruh Kecukupan Modal terhadap Profitabilitas}

Berdasarkan hasil penelitian pada variabel kecukupan modal (CAR) dalam pengujian hipotesis kedua bahwa $\mathrm{H}_{2}$ ditolak, dengan kata lain secara parsial variabel CAR tidak berpengaruh terhadap ROA. Sehingga dapat disimpulkan bahwa kecukupan modal tidak berpengaruh terhadap profitabilitas pada Koperasi BMT Mu'amalah Syari'ah Tebuireng. Hasil penelitian ini mengindikasikan bahwa semakin tinggi tingkat kecukupan modal (CAR) suatu lembaga keuangan tidak menjadi tolak ukur keberhasilan manajemen lembaga keuangan dalam memperoleh laba yang tinggi. Sesuai dengan teori permodalan, modal adalah faktor yang penting dalam rangka pengembangan usaha dan menampung kerugian. Dimana rasio kecukupan modal (CAR), berarti jumlah modal sendiri yang diperlukan untuk menutupi risiko kerugian yang mungkin timbul dari penanaman asset yang mengandung risiko.

Hasil penelitian ini sesuai dengan penelitian Dewi \& Prasetiono (2011), Pasaribu \& Sari (2011), dan Prasetyo \& Darmayanti (2015) yang menunjukkan bahwa CAR tidak berpengaruh terhadap ROA.

\section{Pengaruh Pembiayaan Bermasalah dan Kecukupan Modal terhadap Profitabilitas}

Berdasarkan hasil penelitian pada variabel pembiayaan bermasalah (NPF) dan kecukupan modal (CAR) menunjukkan bahwa pembiayaan bermasalah dan kecukupan modal secara bersama-sama tidak berpengaruh terhadap profitabilitas pada Koperasi BMT Mu'amalah Syari'ah Tebuireng. Hal ini dikarenakan adanya pembiayaan bermasalah yang tinggi akan dapat mengganggu perputaran modal kerja dari lembaga keuangan. Apabila lembaga keuangan memiliki jumlah pembiayaan bermasalah yang tinggi, maka lembaga keuangan akan terlebih dahulu berusaha mengevaluasi kinerja mereka yang dengan sementara menghentikan 
penyaluran pembiayaan hingga pembiayaan bermasalah berkurang. Dari data yang diperoleh, pembiayaan bermasalah yang diukur dengan NPF pada lembaga keuangan cukup sehat karena kurang dari 8\%. Dan kecukupan modal suatu lembaga keuangan tidak selalu menjadi tolak ukur keberhasilan manajemen lembaga keuangan dalam memperoleh laba yang tinggi. Sesuai dengan teori permodalan, modal adalah faktor yang penting dalam rangka pengembangan usaha dan menampung kerugian.

\section{Kesimpulan}

Berdasarkan hasil analisis dan pembahasan yang telah dijelaskan pada bab sebelumnya, maka dapat diambil kesimpulan sebagai berikut: Pada Koperasi BMT Mu'amalah Syari'ah Tebuireng menunjukkan bahwa pembiayaan bermasalah (NPF) secara parsial berpengaruh terhadap profitabilitas (ROA). Hal tersebut ditunjukkan dengan nilai $t$ hitung 2,147 > t tabel 2,035 dan nilai signifikansi 0,039<0,05. Jadi dapat disimpulkan bahwa variabel $X_{1}$ memiliki kontribusi terhadap variabel $Y$ yang berarti berpengaruh. Pada Koperasi BMT Mu'amalah Syari'ah Tebuireng menunjukkan bahwa kecukupan modal (CAR) secara parsial tidak berpengaruh terhadap profitabilitas (ROA). Hal tersebut ditunjukkan dengan nilai nilai t hitung $1,051<\mathrm{t}$ tabel 2,035 dan nilai signifikansi 0,301 >0,05. Jadi dapat disimpulkan bahwa variabel $\mathrm{X}_{2}$ tidak memiliki kontribusi terhadap variabel $\mathrm{Y}$ yang berarti tidak berpengaruh.

Untuk peneliti selanjutnya, disarankan untuk memperluas cakupan penelitiannya, dimana menggunakan variabel-variabel lain selain Pembiayaan Bermasalah dan Kecukupan Modal dengan memasukkan komponen lainnya seperti Efisiensi Operasional, Dana Pihak Ketiga, Likuiditas dan sebagainya, yang secara teoritik berpengaruh terhadap profitabilitas Koperasi BMT Mu'amalah Syari'ah Tebuireng.

\section{Daftar Pustaka}

Aryani, S. W. (2015). Studi analisis pembiayaan bermasalah pada BMT Al-Fattah Pati. UIN Walisongo.

Dewi, D. R., \& Prasetiono, R. (2011). Faktor-faktor yang mempengaruhi profitabilitas Bank Syariah di Indonesia. Universitas Diponegoro.

Ervina, E., \& Aridansari, A. (2016). Pengaruh Dana Pihak Ketiga, Non Performing Financing, Capitaladequacy Ratio dan Return on Asset, terhadap Tingkat 
Likuiditas. Management Analysis Journal, 5(1).

Ferdiansyah, B. E. (2011). Pengaruh Kredit Bermasalah, Tingkat Kecukupan Modal, Tingkat Likuiditas, dan Efisiensi Operasional Perusahaan Terhadap Rentabilitas. Universitas Negeri Semarang.

Kasmir, M. M. (2015). Analisis Laporan Keuangan. Jakarta: Rajawali Pers.

Khusna, A. (2016). Pengaruh biaya operasional dan pembiayaan bermasalah terhadap profitabilitas pada Lembaga Keuangan syariah Asri tulungagung. In Thesis. IAIN Tulungagung.

Lukman, D. (2009). Manajemen Perbankan. Jakarta: Ghalia Indonesia.

Ma'isyah, R., \& Mawardi, I. (2015). Pengaruh Kecukupan Modal, Fungsi Intermediasi, Efisiensi Operasional, dan Pembiayaan Bermasalah terhadap Profitabilitas (Studi Pada Bank Syariah Periode Januari 2010-Juli 2014). Jurnal Ekonomi Syariah Teori Dan Terapan, 2(3).

Malik, A. (2014). Pengaruh budaya organisasi dan loyalitas kerja dengan intensi turnover karyawan pada PT. Cipaganti heavy equipment samarinda. EJurnal Psikologi, 2(1).

Pasaribu, H., \& Sari, R. L. (2011). Analisis tingkat kecukupan modal dan loan to deposit ratio terhadap profitabilitas. Jurnal Telaah $\mathcal{E}$ Riset Akuntansi, 4(2), 114125.

Prasetyo, D. A., \& Darmayanti, N. P. A. (2015). Pengaruh Risiko Kredit, Likuiditas, Kecukupan Modal, Dan Efisiensi Operasional Terhadap Profitabilitas Pada PT BPD Bali. E-Jurnal Manajemen Universitas Udayana, 4(9).

Riyadi, S. (2006). Analisis kinerja dan tingkat kesehatan Bank Danamon setelah rekapitalisasi dan divestasi. In Thesis. Universitas Muhammadiyah Surakarta.

Rustam, B. R. (2013). Manajemen Risiko Perbankan Syariah di Indonesia. Jakarta: Salemba Empat.

Sudana, S. (2016). Pengaruh kecukupan modal dan efisiensi operasional terhadap profitabilitas pada Bank CIMB Niaga Syariah. UIN Sunan Gunung Djati Bandung.

Ulya, A. (2015). Pengaruh Capital Adequacy Ratio (CAR), Financing to Deposit Ratio (FDR), Biaya Operasional dan Pendapatan Operasional (BOPO), dan Dana Pihak Ketiga (DPK) terhadap Tingkat Profitabilitas pada KSU Syariah BMT Kompak. In Thesis. UIN Sunan Kalijaga Yogyakarta. 
Usanti, T. P. (2013). Transaksi Bank Syariah. Jakarta: PT. Bumi Aksara.

Wiagustini, N. P. (2010). Dasar-Dasar Manajemen Keuangan. Denpasar: Udayana University Press.

Wigati, D. A., \& Setiawan, A. H. (2014). Peranan Pembiayaan Mudharabah Terhadap Perkembangan Usaha Mikro Dari Anggota Dan Calon Anggota Koperasi Bmt Mu'amalah Syari'ah Tebuireng Jombang. In Thesis. Fakultas Ekonomika dan Bisnis, UNDIP. 